\title{
10. obletnica Andragoškega centra RS
}

Tehnološki razvoj, ki je nujen za zmanjšanje razvojnega zaostajanja Slovenije za povprečjem EU, ni možen brez vlaganj v človeški kapital oziroma razvoja človeških virov. Vlaganja v človeški kapital sicer ne prinašajo kratkoročnih učinkov, vendar zanemarjanje tega razvojnega vidika oziroma premajhna vlaganja v človeški kapital dolgoročno povzročajo krizo ekonomskega in socialnega razvoja. Staranje prebivalstva, s čimer se Evropa že srečuje in se bo srečevala tudi v prihodnosti ter ga čutimo tudi pri nas, je za družbo poseben izziv. Pomembno je, da starejše prebivalstvo obravnavamo kot heterogeno populacijo. Vsak starejši je posameznik »per se memben zaradi svoje modrosti, znanja in izkušenj. Izobraževanje starejših in hkrati njihovo izobraževanje mlajših, tako imenovano medgeneracijsko izobraževanje, ponujata Andragoškemu centru Republike Slovenije posebne možnosti.

Vendar to ni samo problem financiranja sistemov socialne varnosti, temveč pred aktivno prebivalstvo postavlja zahtevo po vseživljenjskem izobraževanju, pred izobraževalni sistem pa zahtevo po čim večji fleksibilnosti.

Pri obravnavanju izobraževanja in usposabljanja lahko izhajamo iz hamburške deklaracije o izobraževanju odraslih, ki zahteva sodelovanje med ministrstvi, medvladnimi in nevladnimi organizacijami, delodajalci, delojemalci, univerzami, raziskovalnimi inštituti in središči, javnimi občili, civilno družbo ter združenji na lokalni ravni, izobraževalci odraslih in samimi odraslimi. Te usmeritve se kažejo v izobraževanju, pri čemer si odgovor-

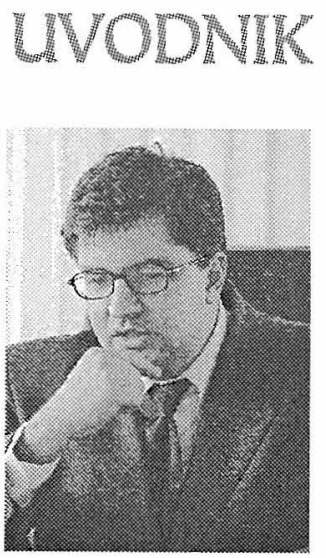

ni za izjemno zahtevne izobraževalne sisteme prizadevajo, da bi, navadno z manj denarja, obravnavali nove izzive in zahteve.

Vloga države je pri tem seveda zagotavljanje dostopnosti izobraževalnih programov in njihove kakovosti s sprejetjem zakonodaje in mehanizmov, ki omogočajo sodelovanje vseh partnerjev.

Vlada Republike Slovenije je $\mathrm{z}$ namenom pospeševanja razvoja izobraževanja odraslih leta 1991 ustanovila Andragoški center Republike Slovenije. Tako je ACS osrednja institucija za raziskovanje, razvoj in svetovanje na področju izobraževanja v Sloveniji.

V 10 letih je postal ACS zaradi pooblastil, ki jih ima na področju izobraževanja odraslih v Slovenji, in položaja, ki ga zavzema v mednarodnem sodelovanju, institucija, ki je ključna za prihodnost. Njeno poslanstvo ni samo raziskovanje na področju izobraževanja odraslih, temveč tudi razvijanje kulture vseživljenskega učenja in izobraževanja odraslih. Sodelovanje, ki ga spodbuja, je hkrati instrument zbliževanja in medsebojnega razumevanja med ljudmi. Posredovanje in delitev znanja, primerjava idej, posvetovanja, ustanavljanje središč za svetovanje, samostojno učenje, širjenje informacij in dosežkov uspešnih poskusov, raziskovanje in ocenjevanje, torej vse, kar center spodbuja v okviru področij, ki spadajo v njegovo dejavnost, je življenjsko pomembno za ustvarjanje sveta, v katerem bo več znanja in medsebojne podpore.

Na podlagi rezultatov dela ACS postaja izobraževanje odraslih kakovostno in množično. To je pomemben razvojni dejavnik Slovenije. 
$\mathrm{Z}$ njim uravnavamo razmerja na trgu delovne sile, preprečujemo odrinjenost nekaterih skupin prebivalstva, izboljšujemo njegovo izobrazbeno in kulturno raven, širimo znanje, povečujemo kakovost življenja ter demokratizacijo družbe in uveljavljamo načelo vseživljenjskosti.

Razvoj človeških virov postavljam v okvir vseživljenjskosti učenja, strategije, v kateri se postopno spreminja nacionalna politika, tako da se izobraževanje otrok ter mladine in izobraževanje odraslih povezujeta $\mathrm{v}$ enoten sistem vseživljenskega učenja, pri spodbujanju izobraževanja odraslih v ACS pa so enakovredno in celostno upoštevane potrebe posameznikov, lokalnega okolja, poslovnega sveta in družbe.

Borze znanja, študijski krožki, središča za samostojno učenje, projektno učenje za mlade, teden vseživljenjskega učenja, preverjanje in potrjevanje znanja, pridobljenega $\mathrm{v}$ neformalnem učenju, certifikatni sistem, razvoj študija na daljavo, razvoj organiziranega samostojnega učenja, ki so neogiben pogoj za izhod iz izobrazbenega zaostanka, individualni izobraževalni računi, standard vlagatelji v ljudi, evalvacija programa 5000 so le nekateri izmed projektov ACS, ki jih je Ministrstvo za delo, družino in socialne zadeve vključilo $\mathrm{v}$ svoje temeljne dokumente strategije zaposlovanja, državni razvojni program in ukrepe aktivne politike zaposlovanja.

Za doseganje ciljev, ki jih upoštevata strategija gospodarskega razvoja Slovenije in strategija zaposlovanja, je pomembno, da ACS učinkovito pripravlja strokovne podlage za razvoj izobraževanja odraslih, razvija in uvaja projekte za pospeševanje izobraževanja odraslih, izvaja naloge, povezane s pripravo, uresničevanjem, spremljanjem ter promocijo izvajanja nacionalnega programa izobraževanja odraslih, in razvija modele informativnosvetovalne službe za izobraževanje odraslih.

dr. Vlado Dimovski 